\title{
ИНСТИТУТ ЗАРАБОТНОЙ ПЛАТЫ: РОЛЬ В НАЦИОНАЛЬНОЙ ЭКОНОМИКЕ БЕЛАРУСИ
}

\author{
Т.Н. Долинина
}

\begin{abstract}
Определены функции заработной платы как результата процесса оплаты труда, выступающего в форме денежного потока, выполняемые в национальной экономике. Исследована роль института заработной платы в национальной экономике Республики Беларусь. Сделаны выводы о значимости этого института в обеспечении инклюзивного развития.
\end{abstract}

Ключевые слова: заработная плата, функции заработной платы, национальная экономика, инклюзивное развитие.

JEL-классификация: J31.

DOI: $10.46782 / 1818-4510-2020-4-66-78$

Материал поступил 20.02.2020 г., после доработки - 7.08.2020 г.

Заработная плата играет исключительную роль в жизни общества. Для многих она выступает основой материального благополучия - люди удовлетворяют свои потребности главным образом за счет заработной платы. От нее также зависит социальное положение в старости, через нее формируются представления о социальной справедливости общественного устройства. Являясь основой личных сбережений граждан, заработная плата определяет динамику развития отраслей национальной экономики. Одновременно с этим она выступает элементом издержек производства. Высокая заработная плата мотивирует нанимателей рационально использовать персонал, внедрять новую технику и современные технологии, ориентирует население на выбор востребованных профессий и т. д. Соответственно, она является центром взаимодействия экономических интересов работников, работодателей и общества в лице государства, которые могут не совпадать. Степень согласованности экономических интересов по уровню и дифференциации заработной платы зависит от развития общества, в том числе от формирования верных теоретических представлений об этой категории и практических подходов к ее использованию.

\section{Заработная плата: функции в национальной әкономике}

Уяснить роль института заработной платы в национальной экономике и обеспечении ее инклюзивного роста и развития позволяет функциональный подход. Являясь результатом процесса оплаты труда, заработная плата может быть представлена: по содержанию - как объем средств, выплачиваемых нанимателем работнику за его труд; по форме - как денежный поток определенной интенсивности, выполняющий ряд функций в экономическом кругообороте $^{1}$. Участвуя в процессах перераспределения и использования доходов, заработная плата как денежный поток выполняет ряд функций, обусловливающих изменение социально-экономической среды, состояние которой, в свою очередь, влияет на уровень заработной платы:

доходообразующую (ключевой элемент доходов работников и их семей);

1 Долинина Т.Н. 2019. Институциональнье модели управления оплатой труда. Ч. 1. Минск: БГТУ. С. 87.

Долинина Татьяна Николаевна (tdolinina@mail.ru), кандидат экономических наук, Белорусский государственный технологический университет (г. Минск, Беларусь). 
финансово-бюджетную (источник налогов, идущих на формирование государственного бюджета);

обеспечения социальных накоплений (отчисления из заработной платы формируют различные социальные фонды);

формирования платежеспособного спроса населения (поддержание обеспеченного денежными средствами потребительского спроса населения на товары и услуги);

инвестиционную (сбережения работников - источник инвестиций в экономику); инновационную (высокая заработная плата стимулирует предпринимателей к использованию трудосберегающих техники и технологий);

статусную (обеспечение определенного общественного положения представителям различных профессий);

профессионально-ориентационную (стимулирует к получению образования и профессиональной подготовки по специальностям с достойной оплатой труда).

Функциональный подход к раскрытию сущности заработной платы позволяет исследовать ее роль в национальной экономике Беларуси.

\section{Доходообразующая функщия заработной плать}

Денежные доходы населения формируются из различных источников. Они включают заработную плату, доходы от предпринимательской и иной деятельнос- ти, социальные трансферты (пенсии, пособия, стипендии и др.), доходы от собственности (проценты по депозитам, дивиденды и др.) и прочие доходы. При этом для подавляющего большинства населения основным источником доходов является заработная плата, для других категорий населения - «привязанные» к ней пенсии и пособия. На долю заработной платы и социальных выплат (трансфертов) населению в 2010-2018 гг. приходилось 83-87\% денежных доходов, непосредственно на оплату труда - 60-65\% (табл. 1). Следовательно, уровень и дифференциацию доходов населения в основном определяют динамика заработной платы, межотраслевые и профессионально-квалификационные различия в оплате труда, поскольку социальные трансферты тяготеют к уравнительности, а доходы от предпринимательской деятельности и собственности доступны ограниченным группам населения. Более того, несмотря на предпринимаемые меры по улучшению делового климата, наблюдается снижение доли доходов от предпринимательской и иной деятельности в денежных доходах населения с 12,7\% в 2010 г. до $8,8 \%$ в 2018 г.

Оценка реализации доходообразующей функции заработной платы предполагает обращение к минимальному уровню доходов населения, определяющему социальное и экономическое здоровье нации. Положительная динамика сокращения бедности в

Таблица 1

Структура денежных доходов населения в Республике Беларусь, \% от общей суммы

\begin{tabular}{|c|c|c|c|c|c|}
\hline Год & $\begin{array}{c}\text { Оплата } \\
\text { труда }\end{array}$ & $\begin{array}{c}\text { Доход от предпринимательской и иной } \\
\text { деятельности, приносящей доход }\end{array}$ & $\begin{array}{c}\text { Трансферты } \\
\text { населению }\end{array}$ & $\begin{array}{c}\text { Доходы от } \\
\text { собственности }\end{array}$ & $\begin{array}{c}\text { Прочие } \\
\text { доходы }\end{array}$ \\
\hline 2010 & 63,1 & 12,7 & 20,4 & 2,5 & 1,3 \\
\hline 2011 & 65,4 & 10,6 & 20,0 & 2,5 & 1,5 \\
\hline 2012 & 63,9 & 10,5 & 20,7 & 3,8 & 1,1 \\
\hline 2013 & 64,1 & 10,3 & 21,8 & 3,8 & 0,8 \\
\hline 2014 & 62,5 & 8,5 & 21,1 & 4,4 & 3,5 \\
\hline 2015 & 61,7 & 8,2 & 22,8 & 4,4 & 2,9 \\
\hline 2016 & 62,0 & 8,0 & 24,2 & 3,3 & 2,5 \\
\hline 2017 & 63,0 & 8,2 & 23,7 & 2,6 & 2,5 \\
\hline 2018 & 64,3 & 8,2 & 22,8 & 2,2 & 2,5 \\
\hline 2019 & 64,2 & 7,8 & 23,3 & \multicolumn{2}{|c|}{4,7} \\
\hline
\end{tabular}

Источник. Авторская разработка на основе: Социальное положение и уровень жизни населения Республики Беларусь, 2016: стат. сборник. 2016. Минск: Национальный статистический комитет Республики Беларусь. C. 60; Структура денежных доходов населения. URL: https://www.belstat.gov.by/ofitsialnaya-statistika/solialnayasfera/uroven-zhizni-naseleniya/denezhnye-dokhody-naseleniya/graficheskiy-material-grafiki-diagrammy/strukturadenezhnykh-dokhodov-naseleniya/ 
2012-2014 гг. сменилась негативной тенденцией роста уровня малообеспеченности в 2015-2017 гг. (табл. 2). В 2018 г. располагаемые ресурсы 5,6\% населения Беларуси не достигали величины бюджета прожиточного минимума.

Статистика показывает, что в Беларуси доля малообеспеченных среди лиц трудоспособного возраста выше, чем среди лиц пенсионного возраста, т. е. в стране помимо традиционной социальной бедности, затрагивающей многодетные и неполные семьи, пенсионеров, инвалидов и другие уязвимые категории граждан, существует экономическая бедность, когда трудоспособные граждане не имеют заработка или получают за свой труд столь низкий заработок, что не могут обеспечить себе и своим семьям социально приемлемый уровень жизни. Кроме того, выход человека за официальную черту бедности еще не означает его автоматического перехода в средний класс. Он, как правило, остается в слое низкообеспеченных людей с угрозой вновь скатиться в бедность при любом изменении своего экономического положения (рождение ребенка, рост инфляции в стране и др.). Чтобы определить группу риска, специалисты используют пороговое значение, равное двум БПМ (Алиев, 2015. С. 111). В 2018 г. более 48\% населения имели уровень среднедушевых располагаемых ресурсов, не превышающий эту черту (в 2014 г. - 43\%).
Помимо показателей абсолютной малообеспеченности, отечественная статистика оценивает показатели относительной и субъективной малообеспеченности. Уровень относительной малообеспеченности в 20102018 гг. составлял 11-14\%, а субъективной колебался в диапазоне от 13 до 20\% (табл. 3). В целом разница в оценках малообеспеченности различными способами достигает двухтрехкратной величины, и то обстоятельство, что малообеспеченность при ее измерении по европейским стандартам касается почти $12 \%$ населения страны, свидетельствует об остроте этой проблемы. Согласно рекомендациям ООН, для поддержания социальной стабильности критически допустимый уровень малообеспеченности не должен превышать 10\% (Морова, 2016).

Признанным индикатором материального благополучия населения является удельный вес расходов на питание в структуре потребления домашних хозяйств. Он определяет структуру остальной части семейного бюджета и возможные расходы по тем статьям, которые типичны для более высокого уровня жизни. Статистика указывает на значительную долю расходов на питание в потребительском бюджете населения Беларуси - более $40 \%$ в сравнении с $30 \%$ в России, $25 \%$ в Польше, $20 \%$ в Чехии, $12 \%$ в Норвегии (табл. 4). По мировым меркам, если затраты населения на питание не превышают 30\% потребительских расходов, возможным

Таблица 2

Доля населения с уровнем среднедушевых располагаемых ресурсов ниже БПМ в Республике Беларусь, \% от численности населения соответствующей группы

\begin{tabular}{|c|c|c|c|c|c|c|}
\hline Год & $\begin{array}{c}\text { Население, } \\
\text { всего }\end{array}$ & $\begin{array}{c}\text { Молодежь } \\
\text { от 16 до 30 лет }\end{array}$ & $\begin{array}{c}\text { Женщины } \\
\text { от 31 до 54 лет }\end{array}$ & $\begin{array}{c}\text { Мужчины } \\
\text { от 31 до 59 лет }\end{array}$ & $\begin{array}{c}\text { Женщины } \\
\text { старше 55 лет }\end{array}$ & $\begin{array}{c}\text { Мужчины } \\
\text { старше 60 лет }\end{array}$ \\
\hline 2010 & 5,2 & 5,6 & 4,8 & 4,5 & 1,8 & 1,1 \\
\hline 2011 & 7,3 & 7,4 & 6,5 & 6,9 & 4,1 & 2,9 \\
\hline 2012 & 6,3 & 7,3 & 5,8 & 5,4 & 2,9 & 2,8 \\
\hline 2013 & 5,5 & 6,3 & 5,2 & 5,0 & 2,4 & 2,1 \\
\hline 2014 & 4,8 & 5,9 & 4,7 & 4,2 & 1,9 & 1,2 \\
\hline 2015 & 5,1 & 6,0 & 5,1 & 4,7 & 1,8 & 1,1 \\
\hline 2016 & 5,7 & 7,0 & 5,7 & 5,3 & 1,8 & 1,6 \\
\hline 2017 & 5,9 & 7,0 & 6,3 & 2,2 & 5,5 & 1,5 \\
\hline 2018 & 5,6 & 6,6 & 5,7 & 2,4 & 5,6 & 1,4 \\
\hline
\end{tabular}

Источник. Авторская разработка на основе: Социальное положение и уровень жизни населения Республики Беларусь, 2016: стат. сборник. 2016. Минск: Национальный статистический комитет Республики Беларусь. С. 86; Социальное положение и уровень жизни населения Республики Беларусь, 2019: стат. сборник. 2019. Минск: Национальный статистический комитет Республики Беларусь. С. 66. 


\begin{tabular}{l}
\hline \multicolumn{3}{c|}{ Таблица 3} \\
Уровень малообеспеченности населения \\
в Республике Беларусь, \\
\% к общей численности населения \\
\begin{tabular}{|c|c|c|c|}
\hline \multirow{2}{*}{ Год } & Уровень малообеспеченности \\
\cline { 2 - 4 } & абсолютной & относительной & субъективной \\
\hline 2010 & 5,2 & 11,7 & 16,6 \\
\hline 2011 & 7,3 & 13,6 & 20,3 \\
\hline 2012 & 6,3 & 14,2 & 14,3 \\
\hline 2013 & 5,5 & 13,6 & 13,8 \\
\hline 2014 & 4,8 & 11,9 & 15,6 \\
\hline 2015 & 5,1 & 12,2 & 14,5 \\
\hline 2016 & 5,7 & 11,5 & 15,7 \\
\hline 2017 & 5,9 & 11,3 & 16,5 \\
\hline 2018 & 5,6 & 11,4 & 12,8 \\
\hline
\end{tabular}
\end{tabular}

Источник. Авторская разработка на основе: Социальное положение и уровень жизни населения Республики Беларусь, 2016: стат. сборник. 2016. Минск: Национальный статистический комитет Республики Беларусь. С. 91; Социальное положение и уровень жизни населения Республики Беларусь, 2019: стат. сборник. 2019. Минск: Национальный статистический комитет Республики Беларусь. С. 71.

считается расширенное воспроизводство человеческих ресурсов, при доле затрат от 30 до $70 \%$ речь идет лишь о простом воспроизводстве населения, если доля затрат свыше $70 \%$ - имеет место его деградация.

При высокой доле расходов населения Беларуси на питание энергетическая ценность его рациона сохраняется ниже порогового значения в 3000 ккал, требуемого для поддержания нормальной жизнедеятельности человека. Рацион питания населения остается несбалансированным по качественным

параметрам, в нем сформировался дефицит потребления по ряду жизнеобеспечивающих продуктов, в частности молока и молокопродуктов, мяса и мясопродуктов, овощей и бахчевых и др. (Кондратенко, Стешиц, 2015). «Качественная структура рациона питания улучшается незначительно, и сдерживающим фактором является покупательная способность реальных денежных доходов населения, которая не позволяет увеличить потребление продуктов с высокой стоимостью» (Гусаков, 2015).

Эффективное преодоление бедности невозможно без понимания факторов, под воздействием которых она формируется. Статистика показывает, что в Республике Беларусь главной причиной бедности является неэффективная и низкооплачиваемая занятость, поскольку доходы Фонда социальной защиты населения, направляемые на выплату социальных трансфертов, связаны с объемом средств, направляемых нанимателем на оплату труда работников.

\section{Финансово-бюджетная функция заработной платы и функция обеспечения сочиальных накоплений}

Ряд функций заработной платы связан с распределительными процессами, обеспечивающими «переформатирование» первичного потока заработной платы (как дохода) в совокупность потоков, направляемых на уплату налогов, социальные накопления, по-

Таблица 4

Доля расходов населения на питание и его калорийность в Республике Беларусь

\begin{tabular}{|c|c|c|c|}
\hline Год & $\begin{array}{c}\text { Доля расходов населения } \\
\text { на питание, } \\
\text { расходребительским } \\
\text { рам домашних хозяйств }\end{array}$ & $\begin{array}{c}\text { Калорийность потребленных в домашних } \\
\text { хозяйствах продуктов питания в среднем } \\
\text { на члена домашнего хозяйства в сутки, } \\
\text { ккал }\end{array}$ & $\begin{array}{c}\text { Дефицитность } \\
\text { калорийности } \\
\text { питания, } \\
\text { \% от норматива }\end{array}$ \\
\hline 2000 & 59,6 & - & - \\
\hline 2005 & 44,6 & 2713 & 9,6 \\
\hline 2010 & 39,0 & 2429 & 19,0 \\
\hline 2011 & 41,3 & 2506 & 16,5 \\
\hline 2012 & 43,0 & 2564 & 14,4 \\
\hline 2013 & 39,9 & 2567 & 11,7 \\
\hline 2014 & 41,6 & 2650 & 11,9 \\
\hline 2015 & 41,9 & 2642 & 12,6 \\
\hline 2016 & 41,5 & 2623 & 13,8 \\
\hline 2017 & 40,7 & 2586 & 14,0 \\
\hline 2018 & 38,9 & 2579 & \\
\hline
\end{tabular}

Источник. Авторская разработка на основе: Социальное положение и уровень жизни населения Республики Беларусь, 2019: стат. сборник. 2019. Минск: Национальный статистический комитет Республики Беларусь. С. 149, 153. 
требление и сбережение. Налоги и отчисления из заработной платы, начисленной наемным работникам (подоходный налог, отчисления в пенсионный фонд и др.), являются значимыми составляющими поступлений в государственный бюджет и Фонд социальной защиты населения.

Налоговая система, обеспечивающая условия для развития общества за счет перераспределения финансовых ресурсов, это важная составляющая экономического организма страны. В Республике Беларусь до 2013 г. подоходный налог с физических лиц занимал третью позицию по объему налоговых поступлений в бюджет после налога на добавленную стоимость и налога на прибыль организаций. С 2013 г. сумма уплаченного физическими лицами подоходного налога заметно превышает сумму налога на прибыль организаций (табл. 5).

В 2009 г. с целью повышения «чистой» заработной платы квалифицированных работников, предотвращения оттока специалистов за рубеж, легализации «теневой» заработной платы в стране введена единая ставка налогообложения физических лиц (12\%). Тем самым приоритеты государственной политики налогообложения были смещены с регулирующей функции подоходного налога с физических лиц на фискальную (единая ставка не создает основы для перераспределения финансовых средств). С тех пор удельный вес этого налога в налоговых поступлениях в консолидированный бюджет демонстрировал устойчивую тенденцию к росту: с 12,0\% в 2010 г. до 17,0\% в 2014 г., что обусловлено как применением единой ставки подоходного налога, так и ростом денежных доходов населения. Однако начиная с 2015 г. его доля стала постепенно сокращаться, несмотря на увеличение с 1 января ставки подоходного налога с $12 \%$ до 13\% в качестве вынужденной меры для обеспечения устойчивости налоговых поступлений. В 2017 г. подоходный налог принес $16,5 \%$ налоговых поступлений доходов бюджета против 17,0\% в 2014 г., что было связано с неустойчивой динамикой заработной платы и сокращением доходов от предпринимательской деятельности в последние годы.

Фонд социальной защиты населения Министерства труда и социальной защиты Республики Беларусь является органом государственного управления средствами государственного социального страхования, которые формируются за счет обязательных страховых взносов субъектов хозяйствования, взносов на профессиональное пенсионное страхование, межбюджетных трансфертов из республиканского бюджета и других источников. Статистика показывает, что в последние годы расходы Фонда социальной защиты населения эквивалентны 24-26\% от суммы оплаты труда работников в СНС, включающей заработную плату и взносы (отчисления) на государственное социальное страхование (табл. 6), что приблизительно соответствует общему объему средств, уплачиваемых в этот фонд организациями (34\% от фонда заработной

Таблица 5

Налоговые доходы и подоходный налог с физических лиц в Республике Беларусь, млрд руб.

\begin{tabular}{|c|c|c|c|c|c|}
\hline \multirow[b]{2}{*}{ Год } & \multirow[b]{2}{*}{$\begin{array}{c}\text { Налоговые } \\
\text { доходы, млн руб. } \\
\text { (2000-2015 гг.) }\end{array}$} & \multicolumn{3}{|c|}{ Из них } & \multirow{2}{*}{$\begin{array}{c}\text { Доля подоходного } \\
\text { налога с физических } \\
\text { лиц в налоговых } \\
\text { доходах, \% }\end{array}$} \\
\hline & & $\begin{array}{c}\text { налог } \\
\text { на добавленную } \\
\text { стоимость }\end{array}$ & $\begin{array}{c}\text { налог } \\
\text { на прибыль }\end{array}$ & \begin{tabular}{|c|} 
подоходный \\
налог \\
с физических лиц
\end{tabular} & \\
\hline 2010 & 44875 & 16226 & 5580 & 5381 & 12,0 \\
\hline 2011 & 73446 & 26499 & 8689 & 9316 & 12,7 \\
\hline 2012 & 138013 & 45457 & 19535 & 19319 & 14,0 \\
\hline 2013 & 164922 & 56223 & 21525 & 26992 & 16,4 \\
\hline 2014 & 189017 & 69829 & 19994 & 32092 & 17,0 \\
\hline 2015 & 222767 & 72671 & 21819 & 37009 & 16,6 \\
\hline 2016 & 23852 & 8235 & 2325 & 3938 & 16,5 \\
\hline 2017 & 26341 & 9248 & 2915 & 4339 & 16,5 \\
\hline 2018 & 31492 & 10552 & 3278 & 5163 & 16,4 \\
\hline
\end{tabular}

Источник. Авторская разработка на основе: Социальное положение и уровень жизни населения Республики Беларусь, 2019: стат. сборник. 2019. Минск: Национальный статистический комитет Республики Беларусь. С. 385. 


\begin{tabular}{|c|c|c|c|}
\hline \multicolumn{5}{c|}{$\begin{array}{c}\text { Таблица 6 } \\
\text { Расходы Фонда социальной защиты } \\
\text { населения в Республике Беларусь }\end{array}$} \\
\begin{tabular}{|c|c|c|} 
Расходы Фонда \\
социальной \\
Защиты \\
Гаселения, \\
млн руб. \\
(2000-2015 гг. \\
- млрд руб.)
\end{tabular} & $\begin{array}{c}\text { Оплата } \\
\text { труда, } \\
\text { млн руб. } \\
(2000- \\
\text { млрд руб.) }\end{array}$ & $\begin{array}{c}\text { Соотношение } \\
\text { расходов } \\
\text { фонда } \\
\text { социальной } \\
\text { защиты } \\
\text { населения } \\
\text { и оплаты } \\
\text { труда СНС, \% }\end{array}$ \\
\hline 2010 & 18377 & 81543 & 22,5 \\
\hline 2011 & 27520 & 125437 & 21,9 \\
\hline 2012 & 56276 & 237726 & 23,7 \\
\hline 2013 & 87500 & 339060 & 25,8 \\
\hline 2014 & 94202 & 397817 & 23,7 \\
\hline 2015 & 108193 & 429285 & 25,2 \\
\hline 2016 & 11542 & 44844 & 25,7 \\
\hline 2017 & 12264 & 49667 & 24,7 \\
\hline 2018 & 13615 & 58216 & 23,4 \\
\hline
\end{tabular}

Источник. Авторская разработка на основе: Социальное положение и уровень жизни населения Республики Беларусь, 2019: стат. сборник. 2019. Минск: Национальный статистический комитет Республики Беларусь. C. 166, 192.

платы работников) и гражданами (1\% от начисленной заработной платы).

Таким образом, при невысоком уровне заработной платы, обусловленном относительно низкой производительностью труда, в последние годы в стране наблюдается усиление ее роли в формировании государственного бюджета и Фонда социальной защиты населения.

\section{Функция формирования платежеспособного спроса населения}

Заработная плата как элемент доходов и, соответственно, последующих расходов работников формирует покупательский спрос на товары и услуги отраслей экономики, который может как способствовать ускорению экономического роста, так и препятствовать его возобновлению. Снижение покупательной способности заработной платы приводит к тому, что население меньше потребляет товаров и услуг. Падение спроса на продукцию ведет к сжатию заказов для предприятий, которые вынуждены сокращать производство на внутренний рынок, что лишает их дополнительной возможности получать доход. Отсутствие дополнительного дохода сказывается на экспортном потенциале субъектов хозяйствования, поскольку сужает источники для инвестирования в основ- ной капитал, вследствие чего они могут оказаться не в состоянии производить конкурентоспособную продукцию, которую можно будет продать на экспорт.

Устойчивый платежеспособный спрос, как правило, формируют средние слои населения. При их отсутствии нет массового спроса, а развитие внутреннего рынка блокируется. Рынок при этом сегментируется: на одном конце образуется элитарный спрос на преимущественно дорогие высококачественные товары, на другом - низкосортные дешевые товары, который нередко также удовлетворяется за счет импорта. Кроме того, важно учитывать, что положительную динамику потребления населения в первую очередь обусловливают рост его доходов, доступность кредитов, а также расширение маркетинговых возможностей в связи с развитием информационных технологий и насаждением мировыми средствами массовой информации потребительских стандартов, изменяющих психологию поведения потребителей. Для интеграции общества крайне важны сбалансированность трудовых и предпринимательских мотиваций потребительских стандартов и их соотношение со средними доходами. Завышенные потребительские стандарты дестимулируют население, поскольку обычные заработки не позволяют их реализовывать. В последние годы соотношение розничного товарооборота и денежных доходов населения и оплаты труда в Республике Беларусь стабилизировалось на уровне 80-82 (табл. 7).

При этом розничный товарооборот, характеризующий изменение потребительского спроса, в 2010-2018 гг. по темпам прироста опережал объемы производства добавленной стоимости. К примеру, среднегодовой темп прироста розничного товарооборота в 2011-2014 гг. составил $11,7 \%$ на фоне 4,7\% ежегодного прироста производительности труда. Это стало фактором, ослабляющим макроэкономическую стабильность и способствующим поддержанию инфляционных процессов ${ }^{2}$. Рост реально-

2 Социально-экономическое развитие Республики Беларусь в 2011-2015 годах и мерь по обеспечению устойчивого сбалансированного развития экономики на перспективу: информационно-аналитический доклад. 2016. Минск: Национальная академия наук Беларуси, Институт экономики НАН Беларуси. 
Динамика розничного товарооборота и оплаты труда в Республике Беларусь

\begin{tabular}{|c|c|c|c|}
\hline Год & $\begin{array}{c}\text { Оплата труда, млн руб. } \\
(2000-2015 \text { гг. }- \text { млрд руб. })\end{array}$ & $\begin{array}{c}\text { Розничный товарооборот, млн руб. } \\
(2000-2015 \text { гг. - млрд руб. })\end{array}$ & $\begin{array}{c}\text { Соотношение розничного } \\
\text { товарооборота и оплаты труда, \% }\end{array}$ \\
\hline 2010 & 81542,7 & 64865 & 79,5 \\
\hline 2011 & 125436,6 & 112899 & 90,0 \\
\hline 2012 & 237726,0 & 202309 & 85,1 \\
\hline 2013 & 339059,9 & 268019 & 89,0 \\
\hline 2014 & 397817,4 & 318100 & 80,0 \\
\hline 2015 & 429285,0 & 347240 & 82,3 \\
\hline 2016 & 44844,4 & 36923 & 81,0 \\
\hline 2017 & 49666,9 & 40237 & 77,6 \\
\hline 2018 & 58215,8 & 45165 & \\
\hline
\end{tabular}

Источник. Авторская разработка на основе: Социальное положение и уровень жизни населения Республики Беларусь, 2019: стат. сборник. 2019. Минск: Национальный статистический комитет Республики Беларусь. С. 20, 21, 192.

го внутреннего потребления в рассматриваемом периоде был обусловлен ростом потребительского импорта (табл. 8).

Диспропорции между встречными денежными и материальными потоками производимых и потребляемых работниками товаров и услуг в белорусской экономике в определенной степени балансировались в результате расширения денежной массы, привлечения государством внешних кредитов и займов, удовлетворения потребностей населения отчасти за счет импорта, усугубившего этот порочный круг. Так, интенсивный внутренний спрос населения в 2010-2013 гг. не смог трансформироваться в адекватную динамику внутреннего производства и привел к росту отрицательного сальдо внешней торговли, финансируемому из золотовалютных резервов за счет накопления внешнего государственного долга. Высокое отрицатель- ное сальдо внешней торговли указывает на завышенность внутреннего потребления по сравнению с производственными возможностями экономики (табл. 9).

Таким образом, повышение заработной платы без адекватного увеличения производительности труда приводит к росту платежеспособного спроса населения и новым дисбалансам в экономике. Наиболее очевидным проявлением такого дисбаланса является рост внешнего государственного долга (Деревяго, 2019).

\section{Инвестиционная и инновационная функции заработной плать}

Часть доходов работников, не использованная на текущее потребление, направляется на сбережение и выступает потенциальным источником инвестиций в развитие национальной экономики или организации.

Динамика реальной заработной платы, розничного товарооборота и импорта

Таблица 8 потребительских товаров в Республике Беларусь

\begin{tabular}{|c|c|c|c|c|c|c|c|}
\hline \multirow[b]{2}{*}{ Год } & \multirow{2}{*}{$\begin{array}{c}\text { Производи- } \\
\text { тельность } \\
\text { труда* , \% }\end{array}$} & \multirow{2}{*}{$\begin{array}{c}\text { Реальная } \\
\text { заработная } \\
\text { плата*, \% }\end{array}$} & \multirow{2}{*}{$\begin{array}{c}\text { Реальные } \\
\text { располагаемые } \\
\text { денежные } \\
\text { доходы } \\
\text { населения , \% }\end{array}$} & \multirow{2}{*}{$\begin{array}{l}\text { Рознич- } \\
\text { ный } \\
\text { товаро- } \\
\text { оборот*, } \\
\text { \% }\end{array}$} & \multicolumn{2}{|c|}{$\begin{array}{c}\text { Импорт потребительских } \\
\text { товаров }\end{array}$} & \multirow{2}{*}{$\begin{array}{c}\text { Покупка } \\
\text { валюты } \\
\text { физическими } \\
\text { лицами, } \\
\text { млн долл. США }\end{array}$} \\
\hline & & & & & $\begin{array}{c}\text { млн долл. } \\
\text { США }\end{array}$ & $\begin{array}{c}\text { \% от общего } \\
\text { объема } \\
\text { импорта }\end{array}$ & \\
\hline 2010 & 107,2 & 115,0 & 114,8 & 115,7 & 5613 & 16,1 & 7696 \\
\hline 2011 & 105,7 & 101,9 & 98,9 & 109,0 & 7054 & 15,4 & 4049 \\
\hline 2012 & 103,5 & 121,5 & 121,5 & 114,1 & 6087 & 13,1 & 6319 \\
\hline 2013 & 101,7 & 116,4 & 116,3 & 118,0 & 7674 & 17,8 & 9193 \\
\hline 2014 & 102,3 & 101,3 & 100,9 & 106,0 & 9173 & 22,6 & 10960 \\
\hline 2015 & 97,4 & 97,7 & 94,1 & 98,7 & 7169 & 23,7 & 7167 \\
\hline 2016 & 99,5 & 96,2 & 93,1 & 95,8 & 6556 & 23,7 & 5723 \\
\hline 2017 & 103,6 & 107,5 & 102,8 & 104,4 & 7693 & 22,5 & 6538 \\
\hline 2018 & 103,4 & 112,6 & 107,9 & 108,3 & 8467 & 22,0 & 7975 \\
\hline
\end{tabular}

Источник. Авторская разработка на основе: Социальное положение и уровень жизни населения Республики Беларусь, 2019: стат. сборник. 2019. Минск: Национальный статистический комитет Республики Беларусь. С. 24, 382, 395.

72 Белорусский экономический журнал № $4 \bullet 2020$ 
Отдельные показатели внешней торговли Республики Беларусь

\begin{tabular}{|c|c|c|c|c|}
\hline Год & $\begin{array}{c}\text { Сальдо внешней торговли } \\
\text { товарамии услугами, } \\
\text { млн долл. США }\end{array}$ & $\begin{array}{c}\text { Валовой внешний } \\
\text { долг, млрд долл. США } \\
\text { (на конец года) }\end{array}$ & $\begin{array}{c}\text { Валовой } \\
\text { внешний долг, } \\
\text { \% от ВВП }\end{array}$ & $\begin{array}{c}\text { Валовой внешний долг } \\
\text { на душу населения, } \\
\text { долл. США/чел. }\end{array}$ \\
\hline 2010 & $-7481,8$ & 28,4 & 49,9 & 2322 \\
\hline 2011 & $-1188,2$ & 34,0 & 55,9 & 2996 \\
\hline 2012 & 2863,2 & 33,8 & 51,5 & 3594 \\
\hline 2013 & $-2300,6$ & 39,6 & 52,7 & 4185 \\
\hline 2014 & $-444,1$ & 40,0 & 50,9 & 4032 \\
\hline 2015 & 132,4 & 38,3 & 67,3 & 3935 \\
\hline 2016 & $-8,8$ & 37,5 & 78,0 & 4204 \\
\hline 2017 & 100,1 & 39,9 & 73,4 & 4116 \\
\hline
\end{tabular}

Источник. Авторская разработка на основе: Социальное положение и уровень жизни населения Республики Беларусь, 2019: стат. сборник. 2019. Минск: Национальный статистический комитет Республики Беларусь. C. 18, 19, 22, 23.

Низкий уровень потребления обостряет проблемы сбыта на внутреннем рынке товаров и услуг; с другой стороны, увеличение потребления сокращает валовое накопление в виде основного капитала, запасов материальных оборотных средств. Выбор населения в пользу потребления, а не сбережения ведет к низкой норме и недостаточному росту внутренних сбережений и, соответственно, внутренних инвестиций, что должно компенсироваться за счет внешних. В текущей экономической ситуации таких традиционных источников инвестиций, как собственные средства предприятий, средства государственного бюджета, иностранные инвестиции, явно недостаточно. В силу этого многие исследователи рассматривают сбережения населения как наиболее значимый и перспективный для Беларуси источник экономического роста. Показателем, характеризующим значимость для национальной экономики депозитов физических лиц, является уровень сбережений населения по отношению к инвестициям в основной капитал. С 2010 г. уровень сбережений населения увеличился с 37,1 до 93,1\% в 2017 г. При слабой динамике инвестиций в основной капитал и сокращении валового накопления основного капитала в ВВП в последние годы сбережения населения становятся важнейшим источником инвестиций (табл. 10).

Высокая заработная плата стимулирует нанимателя к организационно-техническим инновациям, обеспечивающим сбережение труда, замещение живого труда машинным и ведущим к росту производительности труда. Невысокий уровень заработной платы и ее нестабильная динамика в последние годы указывают на слабость этой функции, что подтверждается отечественной статистикой: в стране не наблюдается ожидаемого роста производительности труда на фоне стабильного роста фондовооруженности труда, обусловленного ежегодным обновлением выбывающих основных средств $(5,0-6,3 \%)$, на что указывают стабильный коэффициент их выбытия $(0,7-1,3 \%)$ и снижение степени изноca c $42,1 \%$ в 2010 г. до $38,8 \%$ в 2018 г., а также сокращением численности занятых в экономике. Об этом свидетельствует и динамика фондоотдачи (табл. 11).

Низкая заработная плата блокирует технический прогресс и воспроизводство конкурентоспособной квалифицированной рабочей силы. Использование преимуществ низкой оплаты труда как фактора конкурентоспособности возможно только в относительно короткие периоды времени, в тех случаях, когда расширение высокоэффективного производства на прогрессивной технологической базе (часто на основе импорта технологий) осуществляется за счет интенсивного перелива труда из традиционных секторов экономики (как правило, из сельского хозяйства) или за счет введения в оборот простаивающих резервов (после войн или экономических депрессий). По мере исчерпания резервуара дешевого труда механизм «экономического чуда» перестает действовать. Примером этого выступает современный Китай.

Отсутствие предпосылок для реализации инновационной функции заработной платы указывает на то, что страна оказа- 
Динамика сбережений населения и инвестиций в основной капитал в Республике Беларусь

\begin{tabular}{|c|c|c|c|c|}
\hline Год & $\begin{array}{c}\text { Остатки вкладов населения } \\
\text { в банках (на начало года), } \\
\text { млн руб. (2010-2016 гг. } \\
\text { млрд руб.) }\end{array}$ & $\begin{array}{c}\text { Инвестиции в основной } \\
\text { капитал, млн руб. } \\
(2010-2016 \text { гг. } \\
\text { млрд руб.) }\end{array}$ & $\begin{array}{c}\text { Соотношение } \\
\text { среднегодового остатка } \\
\text { вкладов населения } \\
\text { в банках и инвестиций } \\
\text { в основной капитал, \% }\end{array}$ & $\begin{array}{c}\text { Валовое } \\
\text { накопление } \\
\text { основного } \\
\text { капитала, } \\
\% \text { от ВВП }\end{array}$ \\
\hline 2010 & 18153 & 55381 & 37,1 & 35,5 \\
\hline 2011 & 22957 & 98665 & 36,5 & 38,4 \\
\hline 2012 & 49022 & 154442 & 41,1 & 33,0 \\
\hline 2013 & 78067 & 209575 & 43,0 & 37,1 \\
\hline 2014 & 102339 & 225270 & 52,5 & 29,6 \\
\hline 2015 & 134333 & 207152 & 78,9 & 26,4 \\
\hline 2016 & 192707 & 18710 & 102,5 & 26,6 \\
\hline 2017 & 19073,0 & 21034 & 93,1 & 26,4 \\
\hline
\end{tabular}

Источник. Авторская разработка на основе: Статистический ежегодник Республики Беларусь, 2019: стат. сборник. 2019. Минск: Национальный статистический комитет Республики Беларусь. С. 20-21, 194; Социальное положение и уровень жизни населения Республики Беларусь, 2019: стат. сборник. 2019. Минск: Национальный статистический комитет Республики Беларусь. С. 48; Социальное положение и уровень жизни населения Республики Беларусь, 2016: стат. сборник. 2016. Минск: Национальный статистический комитет Республики Беларусь. С. 63.

Динамика фондовооруженности и производительности труда в Республике Беларусь,

Таблица 11 \% к уровню предыдущего года, в сопоставимых ценах

\begin{tabular}{|c|c|c|c|}
\hline Год & Фондовооруженность труда, & $\begin{array}{c}\text { Индекс производительности труда } \\
\text { по ВВП }\end{array}$ & $\begin{array}{c}\text { Фондоотдача } \\
\text { по ВВП, руб./руб. }\end{array}$ \\
\hline 2010 & 101,9 & 107,2 & 0,381 \\
\hline 2011 & 102,8 & 105,7 & 0,392 \\
\hline 2012 & 103,8 & 103,5 & 0,442 \\
\hline 2013 & 103,6 & 101,7 & 0,416 \\
\hline 2014 & 103,5 & 102,3 & 0,413 \\
\hline 2015 & 103,6 & 97,4 & 0,396 \\
\hline 2016 & 104,5 & 99,5 & 0,371 \\
\hline 2017 & 103,9 & 103,7 & 0,373 \\
\hline 2018 & 103,2 & 103,4 & 0,394 \\
\hline
\end{tabular}

Источник. Авторская разработка на основе: Статистический ежегодник Республики Беларусь, 2019: стат. сборник. 2019. Минск: Национальный статистический комитет Республики Беларусь. С. 24.

лась в ловушке дешевого труда. Низкий доход на душу населения в небогатых странах не позволяет осуществлять сбережения и формирует низкий спрос, что, в свою очередь, ограничивает инвестиции в физический капитал и человеческое развитие. В результате производительность труда и располагаемые доходы на душу населения остаются на низком уровне.

\section{Статусная и профессионально- ориентационная функции заработной плать}

Неизбежным следствием дешевизны труда являются статусные деформации в обществе. Уровень заработной платы влияет на социальный статус и образ жизни работника, престиж профессии на рынке труда. Пропорции в оплате труда отражаются на предпочтениях общества в отношении к различным видам экономической деятельности.

«Оплата труда в Беларуси в буквальном смысле поставлена «с ног на голову» (Rydzeuski, 2015). К примеру, уровень заработной платы в образовании в последние годы ниже, чем в сельском, лесном и рыбном хозяйстве, где заняты работники с самым низким уровнем образования. В этой связи для профессорско-преподавательского состава вузов сегодня характерны не только невысокие уровень и качество жизни, но и отсутствие стабильной мотивации к научно-инновационной деятельности, неопределенность социального статуса. Высшее образование в Беларуси, став массовым за счет новых тех- 
нологий доставки знаний, перестало играть роль фильтра, который пропускал бы только способных и талантливых молодых людей на высший уровень получения профессиональных знаний и компетенций, что позже обеспечивало бы этому ограниченному контингенту престижные и высокооплачиваемые рабочие места. В то же время идет процесс «усложнения социального заказа для учреждений образования. Это подготовка не только высококвалифицированных специалистов, компетентных в сфере будущей профессиональной деятельности, но и ответственных членов гражданского общества, готовых к инновациям и совместной деятельности в условиях сложных социальных трансформаций» (Лапина, Лапина, Цобкало, 2015). Однако тенденции в оплате труда препятствуют этому: образовательные и зарплатные характеристики рабочих мест в Беларуси слабо связаны, тогда как в качестве важнейшей тенденции мирового рынка труда выступает усиление у наемных работников мотивации в росте квалификации, что прослеживается как в оплате труда, так и в связи между образованием и положением работников на рынке труда. К примеру, если 20 лет назад выпускники высших учебных заведений в США получали на 50\% больше, чем выпускники школ, то в настоящее время этот разрыв превысил $80 \%{ }^{3}$.

Неблагополучная ситуация в сфере оплаты труда имеет место не только в образовании, но и в отечественной науке, которая характеризуется сокращением численности исследователей. Продолжительность неблагоприятных тенденций в оплате высококвалифицированного труда создает основу для ослабления конкурентоспособности национальной экономики. Дифференциация заработной платы, сложившаяся по секторам экономики, и падение престижа многих профессий и специальностей, требующих высоких квалификации и качества труда, привели к тому, что значительная часть молодых людей предпочитают работу в наиболее динамично развивающихся отраслях экономики, в основном в информационном, сырьевом, торговом и финансовом секторах. Диспропор-

${ }^{3}$ Залывский Н.П. (Ред.). 2014. Экономика арктических стран: учебное пособие. Архангельск: ИД САФУ. ции в структуре спроса на труд и его предложении в профессиональном, отраслевом, территориальном и других разрезах ограничивают своевременное обеспечение экономики рабочей силой в необходимом количестве и качестве при известной инерционности профессионально-квалификационной структуры.

Со статусной функцией заработной платы тесно связана профессионально-ориентационная функция, которая заключается в формировании ориентации на выбор профессии у лиц, с которыми связан потенциальный приток рабочей силы на рынок труда. В последние десятилетия учреждения высшего образования страны в большей степени были нацелены на подготовку кадров для трансакционных секторов экономики, а инженерные специальности были менее востребованы, поскольку в экономике с масштабным вмешательством государства квалифицированные люди часто выбирают ту деятельность, которая перераспределяет доход (Истерли, 2006. С. 98). Между тем потенциал страны как экономической системы задается состоянием индустриально-технологической базы, стандартами образования, условиями и стимулами массового применения знаний.

\section{На пути к инклюзивному развитиюо}

Итак, заработная плата как финансовый институт выполняет в национальной экономике ряд значимых функций. От их реализации зависит состояние социально-экономической среды, которое в конечном итоге может быть охарактеризовано индикаторами инклюзивного развития, разработанными Всемирным экономическим форумом (рис. 1).

Размер заработной платы сказывается на доходах населения, их уровень в системе индикаторов инклюзивного развития отражается медианным доходом. Невысокий уровень доходов не позволяет снизить уровень бедности, сдерживает рост ожидаемой продолжительности здоровой жизни и не в состоянии преломить неблагоприятные демографические тенденции, которые отражает динамика коэффициента демографической нагрузки (рис. 2).

Заработная плата в составе доходов населения формирует платежеспособный спрос 


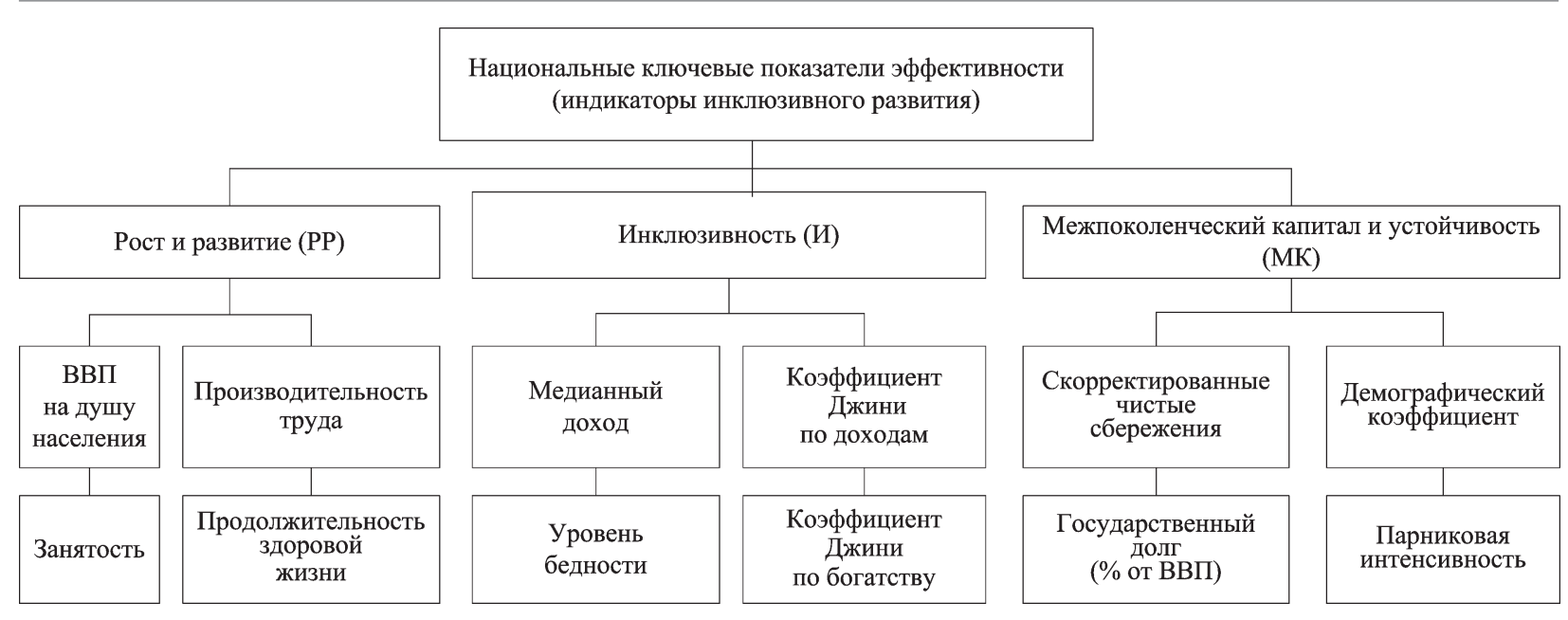

Рис. 1. Национальные ключевые показатели эффективности

Источник. URL: http://reports.weforum.org/the-inclusive-development-index-2018/tables/?doing_wp_cron= 1540561448.7393341064453125000000

\begin{tabular}{|c|c|c|c|c|}
\hline $\begin{array}{c}\text { Валовой } \\
\text { внутренний } \\
\text { продукт } \\
\end{array}$ & $\begin{array}{c}\text { Парниковая } \\
\text { интенсивность }\end{array}$ & $\begin{array}{c}\text { Производительность } \\
\text { труда } \\
\end{array}$ & $\begin{array}{c}\text { Внешний } \\
\text { долг }\end{array}$ & $\begin{array}{c}\text { Валовой } \\
\text { внутренний } \\
\text { продукт } \\
\end{array}$ \\
\hline $\begin{array}{c}\text { Производительность } \\
\text { труда }\end{array}$ & $\begin{array}{c}\text { Инновационная } \\
\text { функция }\end{array}$ & $\begin{array}{c}\text { Статусная } \\
\text { функция }\end{array}$ & $\begin{array}{c}\text { Платежеспособный } \\
\text { спрос }\end{array}$ & $\begin{array}{c}\text { Производительность } \\
\text { труда }\end{array}$ \\
\hline $\begin{array}{c}\text { Чистые } \\
\text { скорректированные } \\
\text { сбережения }\end{array}$ & $\begin{array}{c}\text { Инвестиционная } \\
\text { функция }\end{array}$ & $\begin{array}{l}\text { ЗАРАБОТНАЯ } \\
\text { ПЛАТА }\end{array}$ & $\begin{array}{c}\text { Профессионально- } \\
\text { ориентационная } \\
\text { функция }\end{array}$ & $\begin{array}{l}\text { Занятость } \\
\text { населения }\end{array}$ \\
\hline $\begin{array}{c}\text { Ожидаемая } \\
\text { продолжительность } \\
\text { здоровой жизни }\end{array}$ & $\begin{array}{l}\text { Финансово- } \\
\text { бюджетная } \\
\text { функция }\end{array}$ & $\begin{array}{c}\text { Функция } \\
\text { обеспечения } \\
\text { социальных } \\
\text { накоплений } \\
\end{array}$ & $\begin{array}{c}\text { Доходообразующая } \\
\text { функция }\end{array}$ & $\begin{array}{c}\text { Ожидаемая } \\
\text { продолжительность } \\
\text { здоровой жизни }\end{array}$ \\
\hline $\begin{array}{c}\text { Коэффициент } \\
\text { демографической } \\
\text { нагрузки }\end{array}$ & $\begin{array}{c}\text { Коэффициент } \\
\text { Джини } \\
\text { по доходам } \\
\text { и по богатству }\end{array}$ & $\begin{array}{c}\text { Уровень бедности } \\
\text { Коэффициент } \\
\text { демографической } \\
\text { нагрузки }\end{array}$ & $\begin{array}{l}\text { Медианный } \\
\text { доход }\end{array}$ & $\begin{array}{c}\text { Коэффициент } \\
\text { демографической } \\
\text { нагрузки }\end{array}$ \\
\hline
\end{tabular}

Рис. 2. Взаимосвязь заработной платы с индикаторами инклюзивного развития

Источник. Авторская разработка.

населения. Низкий внутренний спрос неблагоприятно отражается на уровне занятости населения, объеме валового внутреннего продукта и производительности труда, а его рост при перекосах в динамике производительности труда и заработной платы - и на размере внешнего государственного долга.

Величина заработной платы определяет размеры уплачиваемого работниками «подоходного» налога и отчислений в Фонд социальной защиты в бюджет. При низкой заработной плате налоги и отчисления невысоки, что влияет на возможности государственного бюджета по реализации со- циальных программ и Фонда социальной защиты населения - в части выплаты социальных трансфертов, что в конечном итоге опять-таки отражается на медианном доходе, уровне бедности, ожидаемой продолжительности здоровой жизни, коэффищиенте демографической нагрузки, а также на дифференщиащии доходов населения, измеряемой коэффициентом Джини.

Заработная плата формирует не только платежеспособный спрос, но и в определенной мере инвестиционные возможности национальной экономики и инновационные предпосылки развития этой хозяй- 
ственной системы. Невысокая заработная плата определяет слабые инвестиционные возможности ввиду незначительного объема чистых скорректированных сбережений. При низкой заработной плате слабы и инновационные предпосылки - отсутствуют стимулы к замене дешевого землекопа на дорогой экскаватор. Отсюда невысокие показатели объема валового внутреннего продукта и производительности труда на фоне высоких показателей парниковой интенсивности, свидетельствующих о сохранении традиционных III и IV технологических укладов. Шансы попадания в ловушку низкой производительности увеличиваются благодаря диспропорциям в оплате простого и сложного труда, которые приводят к миграции квалифицированных работников и статусным дисбалансам, снижающим мотивацию к труду и, как следствие, его производительность. За дисбалансами статусными следуют профессионально-ориентационные дисбалансы и перекосы на рынке труда, отражаемые на уровне занятости, и т. д. Таким образом, круг индикаторов инклюзивного развития замыкается ${ }^{4}$.

На фоне других стран с переходной экономикой Беларусь по ряду индикаторов выглядит не худшим образом, однако динамика национальных индикаторов ключевых показателей эффективности приближения к развитым странам не демонстрирует, что приводит к выводу об отсутствии инклюзивного роста и необходимости поиска его источников.

Существует мнение, что современная Беларусь находится в «ловушке среднего дохода», под которой понимается ситуация в экономическом развитии, когда страна достигает определенного дохода и «застревает» на этом уровне. Ловушка среднего дохода возникает, когда рост экономики страны замедляется и в конечном итоге останавливается после достижения среднего уровня доходов. Эта проблема обычно возникает у развивающихся стран в связи с ростом заработной платы и снижением ценовой конкурентоспособности продукции, что не позволяет им конкурировать как с развитыми экономиками с высокой

${ }^{4}$ Долинина Т.Н. 2019. Институциональные модели управления оплатой труда. Ч. 2. Минск: БГТУ. 391 с. квалификацией и инновациями, так и с экономиками с низкими доходами, низким уровнем заработной платы и низкими издержками производства. В этой ситуации «основной движущей силой развития экономики становятся внутренние факторы, которые способны воспроизводить сами себя, поддерживая сбалансированный рост» (Деревяго, 2019. С. 36). Основной задачей правительства должна стать разработка комплекса мер, направленных на повышение общего уровня производительности труда в экономике, важных для обеспечения инклюзивного роста.

Инклюзивное развитие предполагает гармонизацию социально-экономических отношений. Согласование интересов индивидов, общества и образующих его социальных групп ради повышения благосостояния и качества жизни населения требует развития экономических институтов, среди которых одно из первых мест по значимости принадлежит заработной плате (Долинина, 2019).

\section{СПИСОК ЛИТЕРАТУРЫ (REFERENCES)}

Алиев Т.М. 2015. Бедность в Казахстане. Мировая экономика и международные отношения. T. 59. № 12. C. 105-115. [Aliev T.M. 2015. Poverty in Kazakhstan. Mirovaya ekonomika i mezhdunarodnye otnosheniya. Vol. 59. No 12. PP. 105-115. (In Russ.)]

Гусаков В.Г. (Ред.). 2015. Продовольственная безопасность Республики Беларусь. Мониторинг - 2014: в контексте сбалансированности развития продуктовых рынков. Минск: Институт системных исследований в АПК НАН Беларуси. [Gusakov V.G. (Red.). 2015. Food Security of the Republic of Belarus. Monitoring-2014: in the context of balanced development of grocery markets. Minsk: Institut sistemnykh issledovaniy v APK NAN Belarusi. (In Russ.)]

Деревяго И.П. 2019. Проблемы формирования эффективной политики экономического роста в Республике Беларусь. Белорусский экономический журнал. № 2. C. 25-37. [Dzeraviaha I.P. 2019. Issues of forming efficient economic growth policy in the Republic of Belarus. Belorusskiy ekonomicheskiy zhurnal. No 2. PP. 25-37. (In Russ.)]

Долинина Т.Н. 2019. Драйверы инклюзивного развития. Минск: Белорусский государственный технологический университет. 252 c. [Dolinina T.N. 2019. Drivers of inclusive development. Minsk: 
Belorusskiy gosudarstvennyy tekhnologicheskiy universitet. 252 p. (In Russ.)]

Истерли У. 2006. В поисках роста: приключения и злоключения экономистов в тропиках. Москва: Институт комплексных стратегических исследований. 352 c. [Easterly W. 2006. In search of growth: the adventures and misadventures of economists in the tropics. Moscow: Institut kompleksnykh strategicheskikh issledovaniy. 352 p. (In Russ.)]

Кондратенко С.А., Стешиц О.В. 2015. Оценка качества жизни и питания населения Республики Беларусь. Проблемы управления. № 1. С. 136147. [Kondratenko S.A., Steshits O.V. 2015. Assessment of the quality of life and nutrition of the population of the Republic of Belarus. Problemy upravleniya. No 1. PP. 136-147. (In Russ.)]

Лапина И.А., Лапина С.В., Цобкало А.А. 2015. Современное образование: качественные критерии и показатели эффективности. Научные труды Республиканского института высшей шко- лы. Философско-гуманитарные науки. № 14. С. $67-$ 71. [Lapina I.A., Lapina S.V., Tsobkalo A.A. 2015. Modern education: Quality criteria and measures of efficiency. Nauchnye trudy Respublikanskogo instituta vysshey shkoly. Filosofsko-gumanitarnye nauki. No 14. PP. 67-71. (In Russ.)]

Морова А.П. 2016 Генезис и законодательное обеспечение социальной политики в Республике Беларусь. Знать, итобы предвидеть... Соииологические этюды. Минск: БГУ. С. 145-160. [Morova A.P. 2016 Genesis and legislative provision of social policy in the Republic of Belarus. Znat', chtoby predvidet'... Sotsiologicheskie etyudy. Minsk: BGU. PP. 145-160. (In Russ.)]

Rydzeuski H. 2015. Minimum wages as the regulator of interregional imbalance of remuneration in Belarus and EU countries. Proceedings of the $5^{\text {th }}$ International Academic Congress «Science, Education and Culture in Eurasia and Africa». Paris: Paris University Press. PP. 314-321.

In citation: Belorusskiy Economicheskiy zhurnal. 2020. No 4. PP. 66-78.

Belarusian Economic Journal. 2020. No 4. PP. 66-78.

\title{
INSTITUTION OF WAGES AND ITS ROLE IN THE NATIONAL ECONOMY OF THE REPUBLIC OF BELARUS
}

\section{Tatyana Dolinina ${ }^{1}$}

\author{
Authors affiliation: ${ }^{1}$ Belarusian State Technological University (Minsk, Belarus). \\ Corresponding author: Tatyana Dolinina (tdolinina@mail.ru).
}

ABSTRACT. The article investigates wages as a result of remuneration in the form of cash flow and defines their functions in national economy. It also examines the role of institution of wages in the national economy of the Republic of Belarus. Conclusions on the importance of this institution in ensuring inclusive development are made.

KEYWORDS: wages, functions of wages, national economy, inclusive development.

JEL-code: J31.

DOI: $10.46782 / 1818-4510-2020-4-66-78$

Received 7.08.2020 